\title{
A Feasibility Study on Waste Utilization in Construction and Review of Waste Generation.
}

\author{
Mala Babagana Gutti
}

B.Eng. Student, Department of Civil and Water Resources Engineering, University of Maiduguri, Maiduguri, Nigeria

Email:malabgutti@gmail.com

\begin{abstract}
This study is aimed at educating the engineering public and professionals on the importance and necessity of waste management, reuse and recycling and also awareness on the benefits of conserving our environment through the reuse and utilization of waste within it. The study has been able to identify the different types of waste with potential of utilization towards construction and several key research factors and criteria which can provide focus and direction towards the choice of waste-type to be used and ensuring that they have utilization potentials in the construction industries.
\end{abstract}

Keywords: - Generation, Waste, Reuse, Utilization, Construction, Materials.

\subsection{Introduction}

Today, many favorable circumstances exist for the useful and beneficial reduction of waste that might have been disposed in our environment but thanks to those recycling, reuses and construction base recovery of waste and the systems that allows such to be feasible. Professionals and management of the Construction industries instructs and train craftsmen to learn how to reuse waste produce in the construction sites so that they never even leave the site as waste. There are 
many economically feasible means of reusing of waste as construction material which can promote environmental well-being and health in general with the employment of the most appropriate means of waste reduction methods for total waste disposal after reuse is complete.

Waste materials are a major environmental problem, which is a threat to the environment. It is important to reuse these materials and dispose of them. Waste can be used in the construction industry in two ways: by reusing (reuse components) and recycling (processing waste into raw materials used in the production of building materials). Overtime, the cost of our day to day construction materials has been increasing rapidly and it is still continually increasing day by day due to the high demand and raw material scarcity, the factor that influence these changes in price is mostly the high cost of energy today. From the point of view of energy conservation and natural resources conservation, there is a rapidly growing concern on the use of alternative components for materials used in construction. For this reason, the scientific and technological professionals now are involved in many different extensive research to develop alternative materials for construction especially using waste as raw materials towards the development of environmental friendly materials for the construction industries and the production of sustainable non-polluting materials for construction. (www.wikipedia.org)

Hilary et. al (1992) Industrial growth has increased the volume of wastes generated from energy production, mining, industrial processes and civil works. For economic and related reasons, the use of waste materials in construction as partial or full replacements for conventional geomaterials has increased. This proceedings, Utilization of Waste Materials in Civil Engineering Construction, consists of papers that discuss policy issues, current practices, performance requirements, engineering characteristics and the potential uses of a wide variety of waste materials in geotechnical systems, highway pavements and construction products. 
Around the world, waste generation rates are rising. In 2016, the world's cities generated 2.01 billion tons of solid waste, amounting to a footprint of $0.74 \mathrm{~kg}$ per person per day. With rapid population growth and urbanization, annual waste generation is expected to increase by $70 \%$ from 2016 levels to 3.40 billion tons in 2050. Managing waste properly is essential for building sustainable and livable cities, but it remains a challenge for many developing countries and cities. Effective waste management is expensive, often comprising $20-50 \%$ of municipal budgets (World Bank, 2018).

The United States Environmental Protection Agency (2015) reports that the total generation of municipal solid waste in 2015 was 262.4 million of which some were recycled. The recycled waste was 67.8 million tons, with paper and paperboard accounting for approximately $67 \%$ of that amount. Metals comprised about $12 \%$, while glass, plastic and wood made up between 4 and $5 \%$.

Waste generation in sub-Sahara Africa is approximately 62 million tons per year. Per capita waste generation is generally low in this region, but spans a wide range, from 0.09 to $3.0 \mathrm{~kg}$ per person per day, with an average of $0.065 \mathrm{~kg}$ per capita per day. The countries with the highest per capita rates are islands, likely due to waste generated by the tourism industry, and a more complete accounting of waste generated (Daniel Hoornweg and Perinaz Bhada-Tata, 2012).

\subsection{Research Methodology}

The data for this study were primarily collected from review of previous research works and the authors understanding and view of the study. Secondary data in this research were obtained from consulting my colleagues and professionals in the field of Civil Engineering, Agricultural Engineering and Mechanical Engineering. 


\subsection{Why Do We Have to Use Waste in Construction?}

There is an expression for long that says "killing two birds with one stone". Well here is where it applies in our research today, here we are focusing on using waste as a primary or secondary material in our construction, because our environment is full of waste today considering the new innovative ways of production is increasing day by day and its waste after use is posing danger to our health and the environment. But by utilizing waste in construction we can be able to achieve two things at the same time, one is that we can now reduce the concentration of waste in our various environments and the second is that we can produce or construct a structure of high performance with waste-base materials as long as they are thoroughly tested and sometimes stabilized to produce an excellent material that can withstand the test of time.

Since we cannot stop or reduce our production, there is always something we can do to minimized waste concentration in our environment and today the most professional way to do that is by utilizing those waste and putting them to use. Today management of waste has become very essential aspect of our sustainable development and building. In this Circumstance, waste management means eliminating waste where possible and ensuring that it is minimize where feasible.

\subsection{Types of Waste Suitable for Utilization in Construction}

The following categories of waste are the most suitable types of waste to be used in the construction industries;

- Agricultural Waste: The organic agricultural waste products have high utilization potential. Organic Agricultural waste like wheat straw, cotton stack, vegetable waste, groundnut shells, orange peels, wheat husk are some good examples. 
- Mineral Waste: The products of mining also produce waste that a suitable and having the potential of utilization in construction, waste like washeries of coal, iron mining waste etc.

- Ceramic-like Waste: These are non-hazardous waste and they make good construction material. Ceramic-like waste can be found in form of lime sludge, broken glass, broken ceramic materials, kiln dust etc.

- Industrial Waste: These are the inorganic waste from industries only and they include steel slag, bauxite, residues of coal combustion etc.

- Other Hazardous Waste: Other Industrial or Workshop base waste that are hazardous in nature like metal working residues, blasting waste, tannery waste, waste water sludge etc. also has a high potential of utilization in construction.

\subsection{Utilization Potential of Waste in Construction}

The employment of solid wastes in construction has come of age, since engineers and scientist started looking for a way to channel waste from within the environment. Solid waste can be used as aggregates or as special cementing material in concrete production. Many studies have focused on the effects of solid wastes on the physical and mechanical properties of construction products. Many of such studies attempted to investigate the durability and performance of solid waste as construction materials. These are some utilization potential of waste in construction;

- Production of high performance concrete.

- Production of construction base fibers.

- Production of polymeric composites.

- Use as Aggregates and Reinforcements.

- Use in Erosion control and Soil stabilization.

- Use in Acoustic control etc. 


\subsection{Research Needs and Comprehensive Applications to Waste Utilization}

The following will guide one to come up with a good waste utilization focus and help ensure it's intended use is achieved;

- Check the availability of a particular waste, it must be in abundant and recorded in tonnage.

- Consider the location where the type of waste is predominantly produced.

- Consider the cost of processing before it is ready for use as a construction material.

- Test the performance or workability of the particular waste and consider any engineering or scientific approach in making workable material.

- Always put in mind that the waste-base material can be used as a primary, secondary or tertiary construction material, such that it will be use as a means of reducing weight or as a stabilizing material etc.

- Make sure that the waste in question has undergo full laboratory testing and has satisfy all the geotechnical, structural and strength aspect of its propose use.

\subsection{Conclusion}

In conclusion, the utilization of waste is turning out to be the savior of tomorrows industrialized and the never ending waste producing world that we are in today. Waste production is now a focus by all the professionals involved with the environment and in engineering, we have now become active parties in researches involving the environment in a very large scale and it has so far yield good results in the field of Environmental and water resources engineering and also Geotechnical engineering. 


\subsection{Recommendations}

The following recommendations will help in further studies on waste utilization if considered;

- Researchers should at least consider exploring the use of other materials that have been then considered not to be a construction material, because it will be very fortunate that today it might be a useful material indeed.

- Research should also perform a continual and advance test on leather waste, because leather waste is abundant in so many part of the world and they do not decompose easily.

- Educational institutions should consider the utilization of waste in construction as final year Project topics for undergraduate students as well as Thesis and Dissertations topic for postgraduate students.

\section{References}

1. Daniel Hoornweg and Perinaz Bhada-Tata, (2012). "What A Waste: A Global Review of Solid Waste Management” Urban Development Series Knowledge Papers, No.15. March, 2012.

2. Hilary I. Inyang, et. al, (1992)." Utilization of Waste Materials in Civil Engineering Construction". American Society of Civil Engineers, New York, NY 978-0-87262-907-3 (ISBN-13). 1992, Soft Cover, Pg. 358.

3. Md. Safiuddin et. al (2010). "Utilization of solid waste in construction materials." International Journal of the Physical Sciences Vol. 5(13), pp. 1952-1963, 18 October, 2010.

4. Ryszard Dachowski and Paulina Kostrzewa. (2016). "The use of waste materials in the construction industry”. Procedia Engineering; vol:161, pages 754-758 open access. 
5. The World Bank (2018). "Solid Waste Management". Understanding Poverty Urban Development .URL: http://www.worldbank.org/en/topic/urbandevelopment/brief.solid$\underline{\text { waste-management }}$

6. The United States Environmental Protection Agency (2015). "National Overview: Facts and Figures on Materials, Waste and Recycling”. Web Material, Accessed: 21 ${ }^{\text {st }}$ Dec, 2018. URL: http://www.epa.gov/facts-and-figure-about-materials-waste-and-recycling/nationaloverview-facts-and-figures-materials

7. http://www.wikipedia.org 